\title{
Pårørende er pasientens livbøye i et tynnslitt helsevesen
}

Mangel på tid og ressurser går på bekostning av pleie og omsorg til pasientene. Da er det de pårørende som må kompensere for nærhet, forståelse, håp og verdighet hos pasienten.

\section{May-Lis Nerhus Bakken}

Virksomhetsleder, Hjelmeland kommune og medlem av Rådet for sykepleieetikk

\begin{tabular}{|l|l|}
\hline Etikk Refleksjon Pårørende Covid-19 \\
\hline
\end{tabular}

Sykepleien 2021109 (83635) (e-83635)

DOI: 10.4220/Sykepleiens.2021.83635

Stadig ressursbesparende tiltak i helse- og omsorgssektoren over flere år, toppet av en pågående covid-19-pandemi, har ført til et tynnslitt helsevesen. Mye tid og ressurser blir prioritert til å håndtere covid19-krisen.

Nye smitteverntiltak, strengere enn noe gang, fører til kontaktforbud mellom pasienten og de pårørende. Livbøyen fra pasientene til de pårørende blir sterkt redusert eller helt borte samtidig som det mangler ressurser til å ivareta pasientenes behov for nærhet. 


\section{Pasienter med afasi er prisgitt journalen}

Et eksempel er en mann jeg kjenner på over 90 år, som er klar og orientert. Hans viktigste verdier i livet er å fylle rollene som ektemann, far, bestefar, svigerfar og venn. Han har afasi, som betyr svikt i evnen til å uttale ord, og apraksi, som er svikt i evnen til å koordinere viljestyrte kroppsbevegelser.

Han ble først innlagt på sykehus for behandling av infeksjon. Noen dager etter, sent på kvelden, ble han videreført til forsterket sykehjem for å fullføre behandlingen.

\section{«Det var ikke mulig med besøk av pårørende den uken han var innlagt på sykehus.»}

Det var ikke mulig med bes $\varnothing \mathrm{k}$ av pårørende den uken han var innlagt på sykehus. Det var heller ikke mulig med besøk fra pårørende etter ankomsten til sykehjemmet siden visittiden var over den dagen. Løsningen ble å kjøre pasienten på utsiden av bygget, $\mathrm{i}$ regn og kulde, slik at han i alle fall kunne få se og snakke med sine pårørende. Det var vått og kaldt $i$ været, men varmt og trygt å se sine kjære.

Med afasi og apraksi blir det nesten umulig å fortelle med ord hvem man er, og hva man trenger. Med afasi er det heller ikke mulig med telefon siden telefonkontakt trenger uttalte ord. Da blir pasienten prisgitt opplysninger som er registrert i journalen som følger med fra en institusjon til en annen. Uten bes $\varnothing \mathrm{k}$ blir det vanskelig, om ikke umulig, å holde kontakten gjennom veggene fra institusjonen og ut til sine kjære.

\section{Hvorfor er nærhetsetikk så viktig?}

Et tynnslitt helsevesen går på bekostning av pleie og omsorg til pasientene. Hvem er det da som kan kompensere for nærhet, forståelse, omsorg, håp og verdighet hos pasienten? Jo, det er pårørende. Uten kontakt med pårørende kan pasientens livshåp og glede forsvinne i takt med timene som går mens de pårørende uteblir. 


\section{«Et tynnslitt helsevesen går på bekostning av pleie og omsorg til pasientene.»}

Hvilke rutiner legger helsevesenet vekt på? Hva mister vi i en hektisk hverdag med stadig mer press på effektivitet, nye krav og rutiner? Hva gjør det med relasjonen mellom pasienten, de pårørende og sykepleieren? Hvordan møter vi våre pasienters behov, og hvorfor er nærhetsetikk så viktig?

Kjernepunktet i nærhetsetikken er møtet med det andre mennesket. Nærhetsetikken forankrer menneskets eksistens og mening i relasjonen med den andre. Den kjente filosofen Emmanuel Lévinas skriver om fordring fra den andres ansikt.

Denne fordringen kan også forstås som en appell og beskrives videre som ordløs, taus og uuttalt. Den er likevel konkret. I møte med hverandre må vi derfor selv resonnere oss frem til hvordan det gagner den andre å bli ivaretatt.

Lévinas er spesielt opptatt av Øynenes og munnens uttrykksfullhet og ville helt sikker ha sagt det på denne måten: Vi blir berørt av den annens lidelse og ønsker å gå den andre i møte for å lindre lidelsen.

\section{Sykepleieren må se pasientens appell}

For å se appellen i pasientens ansikt, la seg berøre og møte lidelsen er det derfor grunnleggende og helt nødvendig for en sykepleier å bruke tid til å være fysisk nær og til stede i møte med pasienten.

Sykepleierne har både kunnskapen, ønsket og viljen, men mangler dessverre ofte tiden. Det bli ekstra utfordrende med pandemi og strenge smittevernregler. 
Afasi gjør det vanskelig å bruke ord når man har behov for hjelp. Med apraksi kan det bli vanskelig å løfte hånden for å tilkalle hjelp. Den sykepleieren som kan hjelpe, er gjerne allerede langt borte i gangen på vei til neste oppgave som venter. Den konkrete avstanden mellom pasienten og sykepleieren blir for stor til å se hånden som vinker, eller høre ordene som ber om hjelp.

\section{Ytre forhold påvirker kontakten}

Tiden med covid-19-pandemi har ført til strenge smittevernregler, rutiner og nye normer, altså ytre forhold. Denne tiden er med på å påvirke hvordan sykepleiere utøver faget sitt. For å redusere smitte er bes $\varnothing \mathrm{k}$ på institusjon sterkt regulert eller helt fraværende.

\section{«Den pårørende er en viktig ressurs og har sin kunnskap om den som er syk.»}

Ytre forhold som regulerte bes $\varnothing \mathrm{k}$ og flere oppgaver som venter, reduserer pasientens tid med sykepleieren, men også de pårørendes kontakt med sykepleieren. Den pårørende er en viktig ressurs og har sin kunnskap om den som er syk.

Når pasienten ikke lenger har samme evne til å formilde sin egenhistorie og behov på grunn av afasi og apraksi, er det den pårørende som kan hjelpe.

Pårørende kjenner pasientens bakgrunn og vet hvilke ressurser og utfordringer pasienten har i forbindelse med sykdommen. Denne dimensjonen er viktig for videre utredning og behandling av den hjelpetrengende.

I eksemplet over var det ikke mulig for pasientens pårørende å benytte seg av visittiden. Det ville ikke hjelpe selv om de pårørende hadde på seg munnbind og var godt kjent med smittevernreglene. Bes $\varnothing$ ket kom etter visittid, og da var døren stengt. 
Er det slik at covid-19 smitter mer eller mindre før eller etter seks på kvelden? Eller kanskje var det «bare» mangel på tid og ressurser til å ta imot bes $\varnothing k$ ?

\section{I en pandemi trengs ekstra tid og ressurser}

Ved å systematisere lærdom og erfaringsutveksling kan vi finne løsninger som kan føre til mer pårørendekontakt ved en eventuell neste pandemi. For å få bukt med smitteomfanget $i$ en pandemitid er vi nødt til å følge regjeringens gjeldende smittevernregler til enhver tid. Det handler om liv og helse.

Forslag til tiltak:

- Opplæring i digitale løsninger til sykepleiere i rolige tider og ikke under en pandemi.

- Bruk av nettbrett som en erstatning for manglende ansikt-til-ansikt-kontakt mellom pasienter og pårørende.

- Egen fast bes $\varnothing$ ksvenn som ivaretar smittevernregler ved pårørendebes $\varnothing \mathrm{k}$, selv utenom visittid.

- Bes $\varnothing k s k a l e n d e r$. Registrere planlagt pårørendebes $\varnothing \mathrm{k}$.

- Bemanning dedikert til informasjon og kontaktpunkt mellom pasienter og pårørende i en tid med besøksforbud.

- Nok smittevernutstyr til bruk ved pårørendebes $\varnothing \mathrm{k}$.

Lege og universitetslektor Peter F. Hjort var opptatt av å se hele mennesket. Han mente blant annet at vi er flinke til å behandle sykdom, men ikke flinke nok til å behandle hele det syke mennesket. Å ha gode løsninger klare ved en eventuell ny pandemi kan styrke oss i arbeidet med å bevare livbøyen mellom pasienten og de pårørende.

Pårørende blir en ressurs og hjelp i behandlingen av pasienten. Slik kan vi bli enda flinkere til å gi sykepleie, ta imot fordringen fra den andres ansikt og gå pasienten $\mathrm{i}$ møte for å lindre lidelse. 
